\title{
Turkish Validity And Reliability Study of Spirituality Index of Well-Being
}

\section{Spiritüel İyilik Ölçeği’nin Türkçe Geçerlilik ve Güvenilirlik Çalışması}

\author{
Esra Serbest *1, Zümrüt Akgün Şahin ${ }^{2}$
}

\begin{abstract}
Objective: The study's goal was to determine the validity and reliability of the Spirituality Index of Well-Being by adapting it to Turkish in accordance with the methodological research type. Methods: This study was conducted on 107 elderly people who applied to four family health centers in the Kars province's center between May 2017 and January 2018 and met the research criteria. A written permission was obtained from the index's creator, the ethical committee, the institution, and individuals. Tools such as the "Introductory Information Form" and the "Spirituality Index of Well-Being" were used to collect data. Results: For the language validity of the index, expert opinions were taken, and a factor analysis was performed for construct validity. According to explanatory factor analysis, it was found out that the index demonstrates a two-factor construct and factor values are in an appropriate range, and according to confirmatory factor analysis it was determined that the two-factor construct of the index is valid and the fit values are appropriate. It was found out that the Cronbach alpha coefficient is 0.858 and total item score correlation coefficient takes value above 0.44 . Conclusion: The Spirituality Index of Well-Being was determined to be a valid and reliable assessment instrument for Turkish society. As a result, it was determined that the scale can be used in clinical practices and research to assess the spiritual well-being of elderly individuals in Turkish society.
\end{abstract}

Key words: Spirituality, aging, validity, reliability

\section{ÖZET}

Amaç: Araştırma Spiritüel İyilik Ölçeği’nin Türkçeye uyarlayarak geçerlilik ve güvenilirliğinin belirlenmesi amacıyla metadolojik araştırma türüne uygun olarak yapılmıştır. Yöntem: Bu çalışma, Kars merkezde bulunan 4 Aile Sağlığı Merkezlerinde, Mayıs 2017-Ocak 2018 tarihleri arasında başvuran ve araştırmaya dahil olma kriterlerini taşıyan 107 yaşlı birey ile gerçekleştirilmiştir. Araştırmada ölçeği geliştiren yazardan, etik kurul, kurum ve bireylerden yazılı olarak izin alınmıştır. Veri toplama aracı olarak "Tanıtıcı Bilgi Formu", "Spiritüel İyilik Ölçeği” kullanılmıştır. Bulgular: Ölçeğin dil geçerliliği için uzman görüşlerine başvurulmuş, yapı geçerliliği için faktör analizi yapılmıştır. Açıklayıcı faktör analizine göre ölçeğin iki faktörlü bir yapı gösterdiği ve faktör değerlerinin uygun aralıkta olduğu, doğrulayıcı faktör analizine göre ise ölçeğin iki faktörlü yapısının geçerli olduğu ve uyum indekslerinin uygun olduğu bulunmuştur. Cronbach $\alpha$ güvenilirlik katsayısının 0.858 olduğu ve madde toplam puan korelasyon katsayısının 0.44 'un üzerinde bir değer aldığı bulunmuştur. Sonuç: Spiritüel İyilik Ölçeği’nin Türk toplumu için geçerli ve güvenilir bir ölçme aracı olduğu belirlenmiştir. Sonuç olarak Türk toplumunda, yaşlı bireylerde spiritüel iyiliği ölçmek amacıyla klinik uygulamalarda ve araştırmalarda ölçeğin kullanılmasının uygun olduğu bulunmuştur.

Anahtar kelimeler: Spiritualite, yaşl1lık, geçerlilik, güvenilirlik

Received / Geliş tarihi: 30.09.2021, Accepted / Kabul tarihi: 27.10.2021

${ }^{1}$ Vocational School of Health Services, Kafkas University, KARS (ORCID: 0000-0001-7141-273X)

${ }^{2}$ Health Science Faculty, Kafkas University, KARS (ORCID: 0000-0002-1515-944X)

*Address for Correspondence / Yazışma Adresi: Health Science Faculty, Kafkas University, Kars-TÜRKIYE

E-mail: zumrut8136@hotmail.com

Tel: +90 5057763209

Serbest E, Şahin AZ. Turkish Validity And Reliability Study of Spirituality Index of Well-Being. TJFMPC, 2021;15(4): 872-878.

DOI: $10.21763 /$ tjfmpc.1002394 


\section{INTRODUCTION}

Aging is a natural and common process that affects all living things, resulting in a reduction in all functions of the body. Aging refers to all of the irreversible structural and functional changes that occur in cells, tissues, organs, and systems over time. ${ }^{1}$ Aging and aging related terms do not have the same meaning. In general, aging is a situation that differs from one person to another and appears after persons feel old themselves. Senility is the final stage of life caused by deterioration in physical health, memory, comprehension, and perception. reduction in perception. ${ }^{2}$

The biological, psychological and social changes in old age cause the elderly individuals to be more sensitive. Thus, many mental disorders ocur. ${ }^{3}$ It has been observed that the level of hope of the patients a high level of spirituality have a higher level of hope, while their proclivity to depression decreases. Increased spiritual well-being aids in better coping with stress and disease and improves overall quality of life. Spirituality maintains one's self-esteem, provides meaning and purpose in life, gives emotional relief and hope. ${ }^{4,5}$ Therefore, nurses should be aware of the spiritual needs of the elderly as well as increasing the social support factors in order to enable the elderly to cope with the physical and mental disorders and increase their quality of life. ${ }^{6}$ Various definitions have been made about spirituality. Spirituality is a personal effort of individuals to understand and accept the meaning of life, their places in the universe, their relations with themselves and their environment. ${ }^{1-3}$ Spirituality includes all elements that are meaningful to a person as a result of his/her own lifelong experiences and acquired knowledge. ${ }^{7-9}$ Spirituality; involves human's search for a supernatural or transcendent meaning, where we come from and where we go, the value, hope and cause of our existence. ${ }^{10}$ Spirituality is the universal term that cannot always be expressed through religion, but it is the driving force that gives life to the human, including biological, psychological and sociological components, regardless of the individual's religious belief. ${ }^{11}$ The importance of spirituality and religion increase especially in their declining years. ${ }^{12}$ The support of patients' spiritual needs is associated with higher life quality, higher hospice utilization, and lower nervousness in end-of-life care. ${ }^{13}$ The spiritual needs of individuals are more complex and more unclear than their physical needs. As an outcome, physical needs of individuals are prioritized in health care services, while spiritual needs may be overlooked. ${ }^{14}$

There is no measurement tool in Turkey to assess the effects of spiritual care on elders. Therefore, it was aimed to study the Turkish validity of the Spirituality Index of Well Being Scale of Daaleman and Frey (2004) in order to assess spiritual well-being in elders and to contribute to nursing care. ${ }^{15}$

\section{METHODS}

This study was methodological design. The study setting was in Kars, a city in eastern Turkey. Data were collected between May 2017-January 2018 from individuals who lived in the catchment areas for four Family Health Center (FHC) regions. The inclusion criteria were as follows: people $\geq 65$ years old, spoke Turkish, had no discernible cognitive impairment, and were willing to participate in the study, and had received a provided home visit. The sample size should be 5-10 times larger than the number of items in the instrument used and expanded by at least $10 \%$ to ensure a sufficient sample size. First, a sample size of at least 60 was calculated because the Spirituality Index of WellBeing Scale has 12 items. This study included 107 elderly people. Participants signed informed consent before completing the questionnaire and participated voluntarily.

\section{Data Collection}

\section{The personal information questionnaire}

Following a review of the relevant literature, the researcher developed a structured questionnaire. ${ }^{15,16}$ For each elderly, demographic information such as age, gender, educational level, marital status, and employment status were recorded. It consists of 5 questions.

\section{Spirituality Index of Well Being}

Daaleman and Frey created the Spirituality Index of Well-Being (SIWB) in 2004 to assess elders' spiritual well-being. Lee and Salman created the Chinese version in Taiwan in 2016.. ${ }^{16}$ It is a 12item scale that measures the perceptions of elderly persons on the spiritual part of life.

It is a five-point Likert type scale and the items of the scale are 1 "strongly agree", 2 "agree", 3 "neutral", 4 "disagree" 5 "strongly disagree". The scale consists of 2 sub-dimensions.

1. dimension refers to the sub-dimension of selfefficacy. This dimension consists of 7 items and contains 1 st, 2 nd, 3rd, 4th, 5th, 6th and 7 th items.

2. dimension refers to the sub-dimension of life plan. This dimension consists of 5 items and contains 8 th, 9th, 10th, 11 th and 12th items.

The SIWB total score ranges from 12 to 60. While a score of 12 indicates poor spiritual well-being, spiritual well-being improves as the 
number of points increases.. The score of 60 indicates the highest spiritual well-being.

\section{Ethical Principles of the Study}

The scale's creators, Daaleman and Frey, given approval to translate the Spirituality Index Of WellBeing Scale into Turkish. The study was approved by the Ethics Committee of Kafkas University Medical School (31.05.2017, No: 2017/06), Medical School, and written permission from Kafkas University, Health Research and Application Center. Furthermore, the elderly who agreed to participate in the study provided verbal consent.

\section{Data collection}

The questionnaire that was used featured the SIWB and questions pertaining to background variables such as age, sex and marital status. Prior to data collection, the interviewers were trained to ensure consistency of application. The older people were interviewed face-to-face by the trained interviewers. To test the stability of the SIWB that is the test-retest reliability-a total of 107 participants agreed to complete the SIWB a second time, 1 week after the initial data collection took place. The number of 107 participants was considered sufficiently. The data collectors visited the older patients in family health center a second time. The test-retest survey was also conducted face-to-face.

\section{Data analysis}

Data analysis was performed by using SPSS (version 16; SPSS Inc., Chicago, IL) and Lisrel 8.0 software (Scientific Software International, Inc., Lincolnwood, IL). Number, percentages, mean, and standard deviations were utilized for the statistical analysis. The analysis and techniques used to conduct validity and reliability analyses are presented below.

\section{Language Validity}

The English version of the SIWB was obtained from its original author for translation. First, a bilingual professional translator translated the English version of the SIWB into Simplified Turkish. Thereafter, another bilingual professional translator translated the translated version back into English. The two translators worked separately. Second, an expert panel of five nursing teachers reviewed the back translation against the original English version and evaluated the cultural and linguistic equivalence of all items. Third, a presurvey using the trial version of the survey was conducted among 20 older people and modifications were performed to item 8 and 12 according to these individuals' feedback of the scale (the final study did not include 20 elderly in this group). These modifications were intended to make the sentences in these items more common, fluent and easier to understand. At last, feature consensus regarding the wording, clarity and cultural equivalence of the Turkish version of the SIWB was achieved.

\section{Content Validity}

After the language adaptation of the scale, Davis technique was used to analyzed the content validity. The opinions of 5 expert academicians in the field were received. The experts were asked to give points to the degree of measurement of each item in the scale between 1 as not appropriate and 4 as very appropriate (17). The Content Validity Index was calculated according to the points given by experts to each item. The CGI score must be at least $0.80 .{ }^{17}$ The CVI was found as 1.00 because the experts gave points the items between 3-4. Therefore, no item was removed from the scale.

\section{RESULTS}

In this study, $61.7 \%$ of the participants were in the age group of 65 to 74 years, $51.6 \%$ of the participants were female, $72.9 \%$ of the participants were married, $43.0 \%$ were illiterate and $90.7 \%$ were unemployed. In the validity analysis of Spirituality Index of Well Being Scale, back translation, Davis method, explanatory factor analysis and confirmatory factor analysis were used for language validity, content validity and structure validity, respectively. In the reliability study of the SIWB, item analysis method was used to measure homogeneity; Cronbach's alpha coefficient was calculated.

Before the analysis of the factor structure of the Spirituality Index of Well Being Scale, Kaiser-Meyer-Olkin was used to assess whether the sample was sufficient for factor analysis while Barlett's Test was used to determine whether the variables were correlated with each other. ${ }^{17,18}$ The KMO value of this study was 0.824 (Table 1 ). This showed that the sample size was sufficient for factor analysis. According to the Barlett's Test result, $\mathrm{x}^{2}=462.963 \mathrm{p}=0.000$ and both test results were found to be significant.

Table 1. KMO and Bartlett's Test Values

\begin{tabular}{ll}
\hline KMO & 0.824 \\
Bartlett & $x^{2}=462.963, \mathrm{p}=\mathbf{0 . 0 0 0}$ \\
\hline
\end{tabular}


Explanatory Factor Analysis (EFA) is used to determine the sub-dimensions of the scale items, if necessary, such as substance addition, subtraction, correction can be made and model can be created by data. ${ }^{19}$ The Spirituality Index of Well Being Scale consisted of 12 items and two subdimensions. The factor loadings of all items in the scale were over 0.40 ; the variances were calculated as $39.453,12.436,51.889$ for the self-efficacy sub- dimension, life plan sub-dimension and total Spirituality Index of Well Being Scale scores, respectively (Table 2 ). For this reason, no item was removed from the scale at this stage and 2 subdimensional structures were accepted. After explanatory factor analysis, confirmatory factor analysis was performed to obtain more accurate results.

Table 2. The factor analysis for Turkish version of Spirituality Index of Well-Being Scale (SIWB-C)

\begin{tabular}{|c|c|c|}
\hline \multirow{2}{*}{ Items } & \multicolumn{2}{|c|}{ Factor I $\quad$ Factor II } \\
\hline & Self-efficacy subscale & Life scheme subscale \\
\hline There is not much I can do to help myself. & 0.739 & 0.030 \\
\hline $\begin{array}{l}\text { Often, there is no way I can complete what I have } \\
\text { started. }\end{array}$ & 0.700 & -0.069 \\
\hline I can't begin to understand my problems. & 0.663 & -0.070 \\
\hline $\begin{array}{l}\text { I am overwhelmed when I have personal difficulties ar } \\
\text { problems. }\end{array}$ & $\mathrm{d} 0.584$ & 0.017 \\
\hline I don't know how to begin to solve my problems. & 0.704 & -0.011 \\
\hline $\begin{array}{l}\text { There is not much I can do to make a difference in my } \\
\text { life. }\end{array}$ & 0.516 & 0.167 \\
\hline I haven't found my life's purpose yet & 0.447 & 0.394 \\
\hline I don't know who I am, where I came from, or where I am goin & 0.188 & 0.664 \\
\hline I have a lack of purpose in my life. & -0.016 & $\mathbf{0 . 7 3 3}$ \\
\hline In this world, I don't know where I fit in. & -0.041 & 0.812 \\
\hline I am far from understanding the meaning of life. & -0.048 & 0.861 \\
\hline There is a great void in my life at this time.. & -0.015 & 0.798 \\
\hline Explained Variance (\%) & 39.453 & 12.436 \\
\hline Total Explained Variance (\%) & 51.889 & \\
\hline
\end{tabular}

For model-data compliance, the compliance criteria must be lower than 5 for the $\mathrm{x} 2$ / SD value, must be lower than 0.08 for the RMSEA and SRMR and must be higher than 0.90 for the GFI, CFI and AGFI. As shown in Table 3, confirmatory factor analysis fit indices of the study were found to be sufficient. $\quad(\mathrm{x} 2 / \mathrm{SD}=1.38, \quad \mathrm{RMSEA}=0.060$, GFI $=0.98 ， \quad$ CFI $=0.98 ， \quad$ AGFI $=0.96 ， \quad$ SRMR $=0.68$, $\mathrm{t}>1.96$ ). Fit indices were found to be acceptable in this study. ${ }^{20-22}$
In Figure 1, the sub-dimensions and item factor loadings of the Spirituality Index of Well Being Scale were presented as a PATH diagram. The factor loadings of the model varied from 0.48 to 0.75 ; ach item had a $\mathrm{t}$ value which was higher than 1.96 .

Item factor loads, fit index results, and PATH diagram of the scale are presented in Table 2 and Table 3 and Fig. 1.

Table 3. CFA results fit index

\begin{tabular}{llll}
\hline Index & Normal value & Acceptable value & Found value \\
\hline$x^{2}$ SSD & $<2$ & $<5$ & 1.38 \\
GFI & $>0.95$ & $>0.90$ & 0.98 \\
AGFI & $>0.95$ & $>0.90$ & 0.96 \\
CFI & $>0.95$ & $>0.90$ & 0.98 \\
RMSEA & $<0.05$ & $<0.08$ & 0.060 \\
SRMR & $<0.05$ & $<0.08$ & 0.068 \\
\hline
\end{tabular}




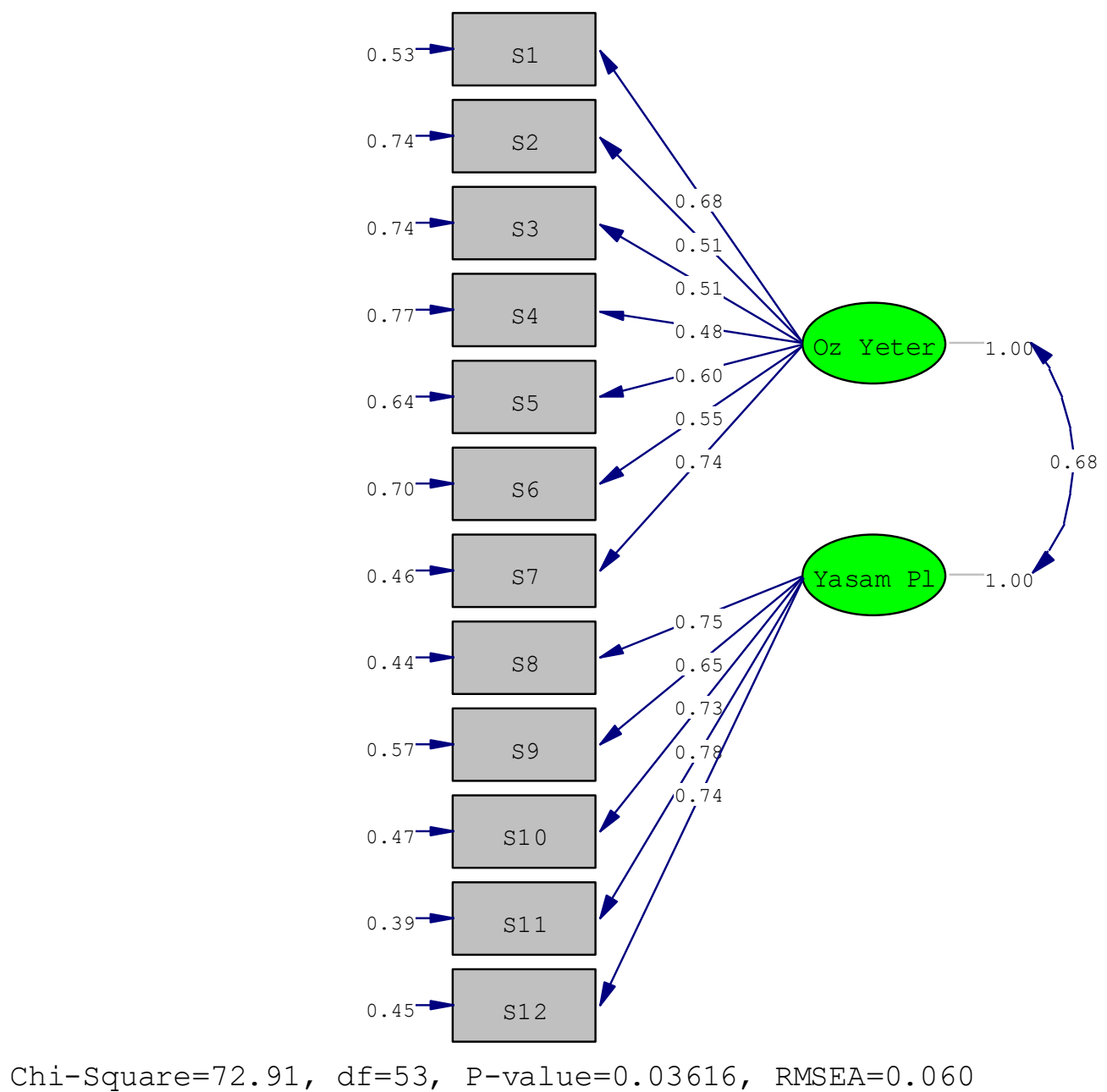

Figure 1: Diagram of the PATH for the Turkish version of Spirituality Index of Well-Being

After the explanatory and confirmatory factor analyses, Cronbach's alpha coefficient was calculated to measure the internal consistency of the scale. As shown in Table 4, the Cronbach alpha coefficient was calculated as $0.858,0.781,0.842$ for the whole Spirituality Index of Well Being Scale, Self Efficacy sub-dimension and life plan subdimension, respectively. The item total score correlations for all items of the scale ranged from 0.40 to 0.64 .

\section{DISCUSSION}

The purpose of this study was to conduct a validity/reliability study of the Spirituality Index of Well Being and adapt the scale to Turkish society. This scale was required because there was no measurement tool in Turkey to assess spiritual wellbeing in the elderly. The main characteristics of a good measurement tool are validity and reliability ${ }^{17}$. In scale validity/reliability studies, language adaptation should be done first. Translating a scale into another language may cause some changes in its structure. As a result, in order to minimize the potential differences, the scale items should be carefully examined, and the necessary arrangements should be made to make the scale meaningful in the translated language. In order to ensure the language validity of the Spirituality Index of Well Being scale, translation-back translation method was used as in the Lee and Salman's study (2016) which the same scale was used for Taiwanese elderly individuals. ${ }^{16}$

Following the translation, the Davis method was used to determine the content's validity. The content validity analysis is performed to examine the scale as a whole to determine the presence of concepts other than the desired concept that was intended to be measured. For content validity, 3-20 expert opinions on the subject should be requested. ${ }^{18-23}$ The validity of the SIWB was determined by consulting the opinions of five expert academicians; the CVI was found to be 1.00 . This finding demonstrates that the Turkish translation of the scale is valid. In order to evaluate the adequacy of the sample size before analyzing the factor structure of the SIWB, the KMO value was determined. The KMO value should be higher than 0.50 . The values of 0.80 and above are 
considered as very good. ${ }^{24}$ In this study, the KMO value was determined as 0.824 ; it showed that the sample size is sufficient for factor analysis.

The factor analysis is carried out in order to ensure that these items are expressed with fewer factors by evaluating whether the items in the scale grouping under different dimensions. ${ }^{17}$ As a result of the Explanatory Factor Analysis (EFA), a model that is suitable for the structure of the data is revealed. ${ }^{17}$ It is stated that the lowest acceptable value for factor loading is 0.30 . while factor loadings of 0.45 and above are a good criteria for selection. ${ }^{25,26}$ In this study, the factor loadings of all items were found to be more than 0.40 , similar to that in the study of Lee and Salman. The factor loadings ranged from 0.48 to 0.75 (Figure 1). The explained variance was $55.86 \%$ in the original scale while it was $51.88 \%$ in this study (Table 2). According to these results, the factor loadings and the explained variance were at a sufficient level. After the EFA, the scale items were analyzed with confirmatory factor analysis; the compatibility of the data set for the theoretical structure was investigated. ${ }^{27}$ The primary objective in the CFA is to test the significance of the relation between the structure and observable variables. CFA is an application to be conducted, especially in the adaptation of previously developed scales. ${ }^{28}$ For the validity of a scale, goodness of fit statistics which are analyzed in confirmatory factor analysis myst be at the desired level. ${ }^{17,27}$ The fit indices in this study were found to be sufficient with " $\mathrm{x} 2 / \mathrm{SD}=1.38, \quad \mathrm{RMSEA}=0.060, \quad \mathrm{GFI}=0.98$, $\mathrm{CFI}=0.98$, AGFI $=0.96, \mathrm{SRMR}=0.68, \mathrm{t}>1.96$ “. On the original scale, all fit indices value were reported to be sufficient except RMSEA value. ${ }^{15}$ In conclusion, the 2-factor structure of the 12-item Spiritual Index of Well-Being Scale was compatible to the model and provided the structural validity of the scale.

In order to measure the internal consistency and homogeneity of the SIWB, item analysis method was used; Cronbach's alpha coefficient was calculated. As the item-total score correlation increases, the effectiveness of the item increases and when the correlation coefficient is low, it is determied that the scale items are not sufficiently reliable. ${ }^{17}$ It is stated that the item-total score correlation coefficient should be at least 0.30 while the values above 0.40 indicate that the items have a well distinguishing characteristic. ${ }^{26}$ The item-total score correlation values of this study ranged between $0.405-0.649$ (Table 4). Since the item-total score correlations of all items were sufficient, no item was excluded from the scale.

The Cronbach's alpha coefficient indicates that whether the items of the scale have sufficient homogeneity. The high cronbach alpha coefficient of a scale indicates that the scale is composed of items that are consistent with each other. The Cronbach's alpha coefficient is highly reliable in the $0.60-0.80$ range and is very highly reliable in the $0.80-1.00$ range. ${ }^{24}$ The Cronbach's coefficient of the SIWB was found to be 0.858 in this study, while the Cronbach's coefficients for self-efficacy and life plan sub-dimensions were 0.78 and 0.84 , respectively (Table 4). The scale was extremely dependable. The original scale has a high reliability coefficient as well. The original scale's Cronbach's alpha coefficient is $0.92,0.86$, and 0.89 for the whole scale, self efficacy, and life plan subdimensions, respectively. ${ }^{15}$

\section{CONCLUSION}

The research was carried out in a province center. As a result, it is unclear whether these findings are applicable to other regions or countries. The study only included elderly people. This is yet another study limitation. According to the current study's findings, the SIWB was found to be a valid and reliable instrument for Turkish society. The SIWB's consistency is sufficient. The SIWB can be used as an assessment tool for measuring elders' perceptions of spiritual well-being and contributing to clinical care.

This research is a master thesis.

\section{REFERENCES}

1. Harrington D. Confirmatory Factor Analysis. New York, NY: 1th edition; 2009: 21-36.

2. Arslan N.Living Deep. Turkey, İstanbul: 4th edition; 2015: 10-301. (Turkish)

3. Erden AÖ. Primary Geriatrics for Primary Care. In: Gökkaya OKN,eds. Psychiatric Problems in the Elderly. Turkey, Ankara: 1th edition; 2012: 34-39. (Turkish)

4. Büssing A, Koenig HG. Spiritual needs of patients with chronic diseases and cancer. Validation of spiritual needs questionnaire. Eur J Med Res. 2010;1(1):18-27

5. Büssing A. The spREUK-SF 10 questionnaire as a rapid measure of spiritual search and religious trust in patients with chronic diseases. Zhong Xi Yi Jie He Xue Bao. 2010;8(9):83241.

6. Boztilki M, Ardıç E. Spirituality and health. G.O.P. Taksim E.A.H. JAREN. 2017;3:39-45. (Turkish)

7. Arslan H, Konuk Şener D. Studying the concepts of stigma, spirituality and comfort in accordance with meleis' concept development process. Maltepe Üniversitesi Hemşirelik Bilim ve Sanatı Dergisi. 2009;2(1): 51-58. (Turkish) 
8. Kiper S, Uçak A, Alp Yılmaz F. Views from the different religions in the end of life care. Yoğun Bakım Hemşireliği Dergisi. 2011; 15(2): 67-71. (Turkish)

9. Gönenç İM, Akkuzu G, Durdun Altın R, Moroy P. Views of nurses and midwives on spiritual care. Gümüşhane Üniversitesi Sağlık Bilimleri Dergisi. 2016; 5(3):34-38. (Turkish)

10. Reed J, Clarke C, Macfarlane A. In: Karadakovan A eds. Nursing Older Adults. Turkey, Ankara; 2015:176-191. (Turkish)

11. Como JM. Spiritual practice: a literatüre review related to spiritual health and health outcomes. Holist Nurs Pract.2007;21(5):224236.

12. Sulmasy DP. Spiritual issues in the care of dying patients: "it's okay between me and god. JAMA. 2006; 296: 1385-1392.

13. Balboni TA, Paulk ME, Balboni MJ et al. Provision of spiritual care to patients with advanced cancer: associations with medical care and quality of life near death. J Clin Oncology. 2010; 28: 445-452.

14. Sülü Uğurlu E, Başbakkal Z. Spiritual care requirements of the mothers of the hospitalized children in intensive care units. Türk Yoğun Bakım Derneği Dergisi. 2013;11:17. (Turkish)

15. Daaleman TP, Frey BB: The spirituality index of well-being: a new instrument for healthrelated qualitybof life research. Ann Fam Med. 2004;2(5):499-503.

16. Lee H, Salman A. Evaluation of using the Chinese version of the Spirituality Index of Well-Being (SIWB) scale in Taiwanese elders. Appl Nurs Res. 2016; 32: 206-211.

17. Erdoğan S, Nahcivan N, Esin N. Research in Nursing: Process, Qualification and Critical. Turkey, İstanbul; 2014: 56-189. (Turkish)

18. Özdamar K.Statistical Data Analysis with Package Programs. Turkey, Eskişehir; 2004: 450-455. (Turkish)

19. Capik C. Use of confirmatory factor analysis in validity and reliability studies. Anadolu Hemşirelik ve Sağlık Bilimleri Dergisi. 2014;17(3):196-205. (Turkish)

20. Schumacker RE, Lomax RG. A Beginner's Guide to Structural Equation Modeling. London, New York; 2010: 245-269.

21. Waltz CF, Strcikland OL, Lenz ER. Measurement in Nursing and Health Research. London, New York; 2010: 183-209.

22. Wang J, Wang $X$. Structural Equation Modeling: Applications Using Mplus: Methods and Applications. China, West Susex; 2012: 58-77.

23. Karasar N. Scientific Research Methods. Turkey, Ankara; 2012: 75-107. (Turkish)

24. Akgül A. Statistical Analysis Techniques in Medical Research and SPSS Applications. Turkey, Ankara; 2003: 440-446. (Turkish)
25. Harrington D. Confirmatory Factor Analysis. London, New York; 2009:21-35.

26. Büyüköztürk Ş. Manual of data analysis for social sciences. Turkey, Ankara; 2011: 167182. (Turkish)

27. Şimşek Ö. Introduction to Structural Equation Modeling: Basic Principles and Applications of Lisrel. Turkey, Ankara; 2007: 74-99. (Turkish)

28. Eser E. Conceptual basis and measurement of health related quality of life. Sağlıkta Birikim Dergisi; 2006; 5:1-5. (Turkish) 